Article

\title{
Preparative Isolation and Purification of Five Flavonoid Glycosides and One Benzophenone Galloyl Glycoside from Psidium guajava by High-Speed Counter-Current Chromatography (HSCCC)
}

\author{
Yindi Zhu ${ }^{1,2}$, Yue Liu ${ }^{3}$, Ying Zhan ${ }^{1,2}$, Lin Liu ${ }^{1,2}$, Yajuan $\mathrm{Xu}^{3}$, Tunhai Xu ${ }^{1,2, *}$ and Tonghua Liu ${ }^{2}$ \\ 1 Department of Traditional Chinese Medicine Chemistry, School of Traditional Chinese Medicine, \\ Beijing University of Chinese Medicine, No. 6 Wangjing Zhonghuan South Road, \\ Chaoyang District, Beijing 100102, China; E-Mails: zhuyindi314@sina.com (Y.Z.); \\ zhanying0918@163.com (Y.Z.); lyn9500@163.com (L.L.) \\ 2 Health-cultivation Laboratory of the Ministry Education, Beijing University of Chinese Medicine, \\ 11 North Third Ring Road East, Chaoyang District, Beijing 100029, China; \\ E-Mail: thliu@tom.com \\ 3 Chemistry of Chinese Medicine, Jilin Academy of Chinese Medicine Sciences, Changchun 130021, \\ China; E-Mails: ydzh33@126.com (Y.L.); xyj6492@sohu.com (Y.X.) \\ * Author to whom correspondence should be addressed; E-Mail: thxu@163.com; \\ Tel./Fax: +86-10-6428-6935.
}

Received: 17 October 2013; in revised form: 9 December 2013 / Accepted: 10 December 2013 / Published: 16 December 2013

\begin{abstract}
Psidium guajava leaves have a diverse phytochemical composition including flavonoids, phenolics, meroterpenoids and triterpenes, responsible for the biological activities of the medicinal parts. In particular, flavonol glycosides show beneficial effects on type II diabetes mellitus. A simple and efficient HSCCC method has been developed for the preparative separation of five flavonoid glycosides and one diphenylmethane glycoside from P. guajava. A solvent system composed of $n$-hexane-ethyl acetate-methanol-water $(0.7: 4: 0.8: 4, \mathrm{v} / \mathrm{v} / \mathrm{v} / \mathrm{v})$ was optimized for the separation. The upper phase was used as the stationary phase, and the lower phase was used as the mobile phase. Under the optimized conditions, hyperoside $(15.3 \mathrm{mg})$, isoquercitrin $(21.1 \mathrm{mg})$, reynoutrin $(65.2 \mathrm{mg})$, quercetin-3- $O-\beta$-D-arabinopyranoside $\quad(71.7 \mathrm{mg})$, quercetin-3- $O-\alpha$-L-arabinofuranoside (105.6 mg) and 2,4,6-trihydroxy-3,5-dimethylbenzophenone 4-O-(6"-O-galloyl)- $\beta$-Dglucopyranoside $(98.4 \mathrm{mg}$ ) were separated from crude sample $(19.8 \mathrm{~g})$. The structures of all
\end{abstract}


the isolates were identified by ESI-MS, ${ }^{1} \mathrm{H}$ - and ${ }^{13} \mathrm{C}-\mathrm{NMR}$ analyses and their purities $(>95 \%)$ were determined using HPLC.

Keywords: HSCCC; flavonoid glycosides; benzophenone galloyl glycoside; Psidium guajava

\section{Introduction}

Psidium guajava (guava), an important food crop and medicinal plant in tropical and subtropical countries, is widely used as a food and in folk medicine around the World. It is a native to Mexico and extends throughout South America, Europe, Africa and Asia [1,2]. Guava fruits are beneficial for health [3], protecting kidney against diabetic progression via their anti-oxidative, anti-inflammatory and anti-glycative effects [4]. Guava leaves are used for the treatments of type II diabetes mellitus [5] and diarrhoea [6], showing hypoglycemic [7,8], antioxidant [9,10], anti-inflammatory [11], anticancer [12] gastro protective [13] and antipathogenic microorganism effects [14].

Previous phytochemical studies have demonstrated that phenolics [15], flavonoids [16], meroterpenoids [17,18] and triterpenes [19] were the major bioactive constituents of $P$. guajava leaves. Flavonol glycosides of guava have beneficial effects for type II diabetes mellitus by inhibiting dipeptidyl peptidase activity [20], and adipogenesis in 3T3-L1 preadipocytes via down-regulation of PPARg and C/EBP a expression [21]. Hyperoside has a great number of biological effects, such as anti-inflammatory, anticancer and antioxidant activities [22], quercetin, an antioxidant, has a preventive effect on thioacetamide-induced liver cell necrosis [23], reynoutrin showed a-glucosidase inhibitory activity [24], quercetin-3- $O-\beta$-D-arabinopyranoside and quercetin-3- $O-\alpha$-L-arabinofuranoside possess antibacterial and antifungal activities [25] and 2,4,6-trihydroxy-3,5-dimethylbenzophenone 4-O-(6"-O-galloyl)- $\beta$-D-glucopyranoside showed significant inhibitory activities against histamine release from rat peritoneal mast cells [26].

Traditional isolation techniques for these components have required the use of multiple steps employing column chromatography, medium-pressure liquid chromatography, vacuum column chromatography, preparative HPLC, or combinations of these techniques [18]. However, high-speed counter-current chromatography, which is free of irreversible adsorption [27], is capable of isolating multiple components from plant extracts, with added benefits over traditional methods, including no losses and lower solvent use and has been widely used in preparative separation of natural product [28,29].

In this paper, we report a new method using HSCCC and semi-preparative HPLC for the isolation and purification of five flavanoids and one benzophenone galloyl glycoside (Figure 1) from P. guajava leaves, four of which were purified using only the HSCCC separation, while a hyperoside and isoquercitrin mixture was separated by semi-preparative liquid chromatography. 
Figure 1. Chemical structures of five flavonoid glycosides and one benzophenone galloyl glycoside from of $P$. guajava leaves: quercetin-3-O- $\beta$-D-galactopyranoside (1), quercetin3- $O$ - $\beta$-D-glucopyranoside (2), quercetin-3- $O-\beta$-D-xylopyranoside (3), quercetin-3- $O-\beta$-Darabinopyranoside (4), quercetin-3-O- $\alpha$-L-arabinofuranoside (5), 2,4,6-trihydroxy-3,5dimethylbenzophenone 4- $O$-(6"-O-galloyl)- $\beta$-D-glucopyranoside (6).<smiles>O=c1c(O[C@@H]2O[C@H](CO)[C@@H](O)[C@H](O)[C@H]2O)c(-c2ccc(O)c(O)c2)oc2cc(O)cc(O)c12</smiles><smiles>O=c1c(O[C@@H]2O[C@H](CO)[C@@H](O)[C@H](O)[C@H]2O)c(-c2ccc(O)c(O)c2)oc2cc(O)cc(O)c12</smiles><smiles>O=c1c(O[C@@H]2OC[C@@H](O)[C@H](O)[C@H]2O)c(-c2ccc(O)c(O)c2)oc2cc(O)cc(O)c12</smiles><smiles>O=c1c(OC2OC[C@@H](O)[C@H](O)[C@H]2O)c(-c2ccc(O)c(O)c2)oc2cc(O)cc(O)c12</smiles><smiles>O=c1c(O[C@@H]2O[C@H](CO)[C@@H](O)[C@H]2O)c(-c2ccc(O)c(O)c2)oc2cc(O)cc(O)c12</smiles><smiles>Cc1c(O)c(C(=O)c2ccccc2)c(O)c(C)c1OC(O)CCOC(=O)c1cc(O)c(O)c(O)c1</smiles>

\section{Results and Discussion}

\subsection{Solvent System Selection}

A suitable solvent system plays an important role in separation by HSCCC. The system in which the main compounds could partition in the two phases with partition coefficients about $0.5-5$ was used for HSCCC separation [30]. A smaller $K$ value elutes the solute closer to the solvent front with lower resolution while a larger $K$ value tends to give better resolution but broader, more dilute peaks due to a longer elution time. In this experiment, the ethyl acetate extract was analyzed by HPLC-UV and 6 major unknown peaks were targeted for further separation by HSCCC. Two-phase solvent systems with $n$-hexane-ethyl acetate-methanol-water (1:1:1:1, 1:2:1:2, 1:3:1:3, 1:4:1:4, 1:5:1:5, 1:6:1:6, $0.7: 4: 0.8: 4,0.3: 3: 0.1: 3)$ were tested according to the polarity of the target compounds, and the results are shown in Table 1.

When the target analyte is unknown, the search may start at $n$-hexane-ethyl acetate-methanolwater $(1: 1: 1: 1, \mathrm{v} / \mathrm{v})$ and then follow the direction indicated by $K$ values [31]. The first solvent system of $n$-hexane-ethyl acetate-methanol-water $(1: 1: 1: 1)$ was tested, and the analytes were eluted close to the solvent front with poor separation, whereas a gradual decrease in the volume ratio of $n$-hexane and water yielded a better resolution. Finally, good separation results of the ethyl acetate extract were obtained using the solvent system of $n$-hexane-ethyl acetate-methanol-water (0.7:4:0.8:4). A solvent 
system consisting of $n$-hexane-ethyl acetate-methanol-water $(0.3: 3: 0.1: 3, \mathrm{v} / \mathrm{v} / \mathrm{v} / \mathrm{v})$ was used for the purification of mixture of $\mathbf{1}(K=1.27)$ and $\mathbf{2}(K=1.19)$. A solvent system consisting of $n$-hexane-ethyl acetate-methanol-water (0.7:4:0.8:4) was used for the purification of compound $\mathbf{3}(K=1.28), \mathbf{4}(K=1.68)$ and $5(K=2.64)$. A solvent system consisting of $n$-hexane-ethyl acetate-methanol-water $(1: 3: 1: 3)$ was used for the purification of $6(K=1.06)$.

Table 1. $K$ values of compounds 1-6 from $P$. guajava leaves in two-phase solvent systems ( $n$-hexane-ethyl acetate-methanol-water) for HSCCC separation.

\begin{tabular}{ccccccc}
\hline \multirow{2}{*}{ Solvent Ratio } & \multicolumn{7}{c}{ Partition Coefficient $\left(\boldsymbol{K}_{\mathbf{U} / \mathbf{L}}\right)$} \\
\cline { 2 - 7 } & $\mathbf{1}$ & $\mathbf{2}$ & $\mathbf{3}$ & $\mathbf{4}$ & $\mathbf{5}$ & $\mathbf{6}$ \\
\hline $1: 1: 1: 1$ & 0.27 & 0.30 & 0.09 & 0.06 & 0.07 & 0.08 \\
$1: 2: 1: 2$ & 0.09 & 0.11 & 0.18 & 0.24 & 0.32 & 0.41 \\
$1: 3: 1: 3$ & 0.14 & 0.17 & 0.33 & 0.46 & 0.65 & 1.06 \\
$1: 4: 1: 4$ & 0.40 & 0.43 & 1.07 & 1.48 & 2.28 & 3.94 \\
$1: 5: 1: 5$ & 0.32 & 0.34 & 0.88 & 1.25 & 1.90 & 3.66 \\
$1: 6: 1: 6$ & 0.48 & 0.51 & 1.47 & 2.03 & 3.43 & 6.57 \\
$0.7: 4: 0.8: 4$ & 0.50 & 0.53 & 1.28 & 1.68 & 2.64 & 4.40 \\
$0.3: 3: 0.1: 3$ & 1.27 & 1.19 & 4.10 & 5.67 & 11.03 & 26.64 \\
\hline
\end{tabular}

\subsection{HSCCC Separation}

Under the optimized conditions, the crude extract (600 mg) was subjected to HSCCC, and the resulting HSCCC chromatogram is shown in Figure 2.

Figure 2. HSCCC chromatogram of the ethyl acetate extract from P. guajava leaves. (a) Ethyl acetate extract from $P$. guajava leaves, (b) first time purification of mixture of compound 1 and compound 2 and (c) second time purification of mixture of compound 1 and compound 2 .

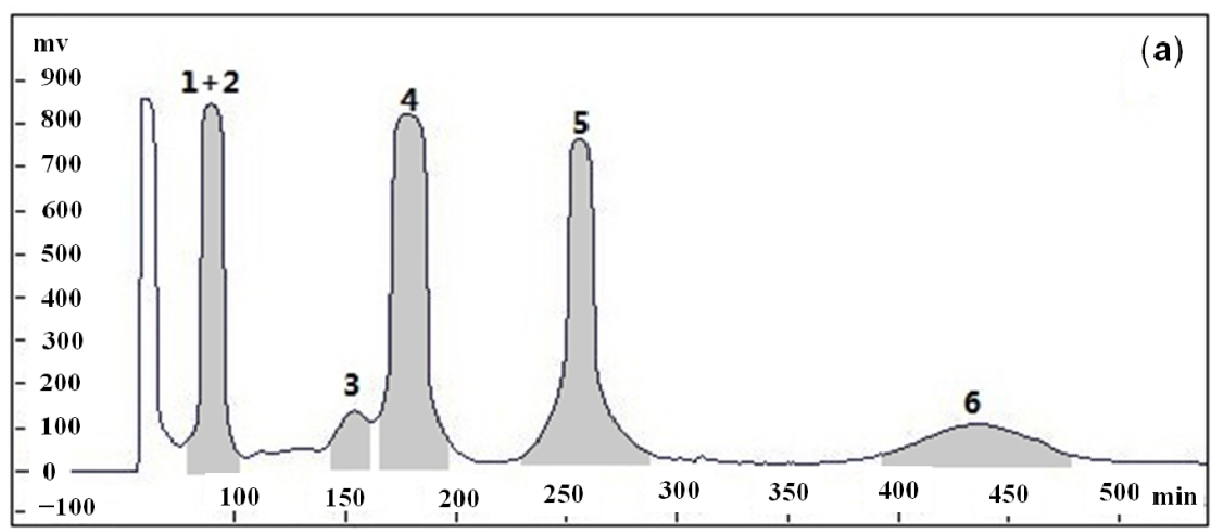


Figure 2. Cont.
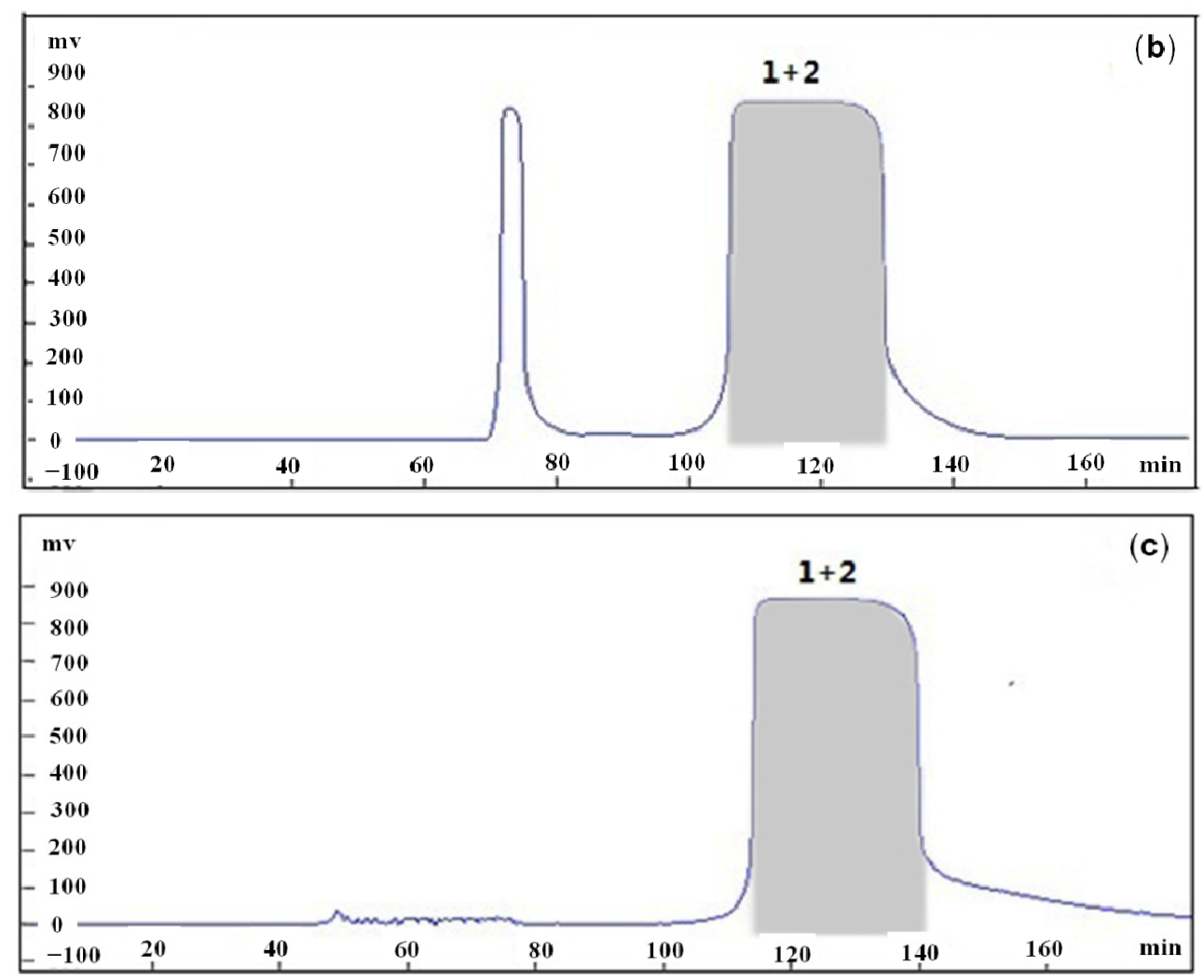

Five fractions were obtained, each fraction was further purified by HSCCC, and then mixture of compounds 1 and 2 were separated by semi-preparative HPLC, resulting in the isolation of six compounds: 1 (15.32 mg), 2 (21.12 mg), 3 (65.15 mg), 4 (71.69 mg), 5 (105.57 mg) and 6 (98.43 mg). The crude sample and peak fractions separated by HSCCC and semi-preparative HPLC were analyzed by HPLC, under the optimum analytical conditions, and the chromatograms are presented in Figure 3.

Figure 3. HPLC chromatograms of ethyl acetate extract from P. guajava leaves and HSCCC peak fractions. (A) Ethyl acetate extract from P. guajava leaves, (B-C) the two targeted compounds (compounds 1 and 2) purified by HSCCC. (D-G) the four targeted compounds (compound 3-6) purified by HSCCC.

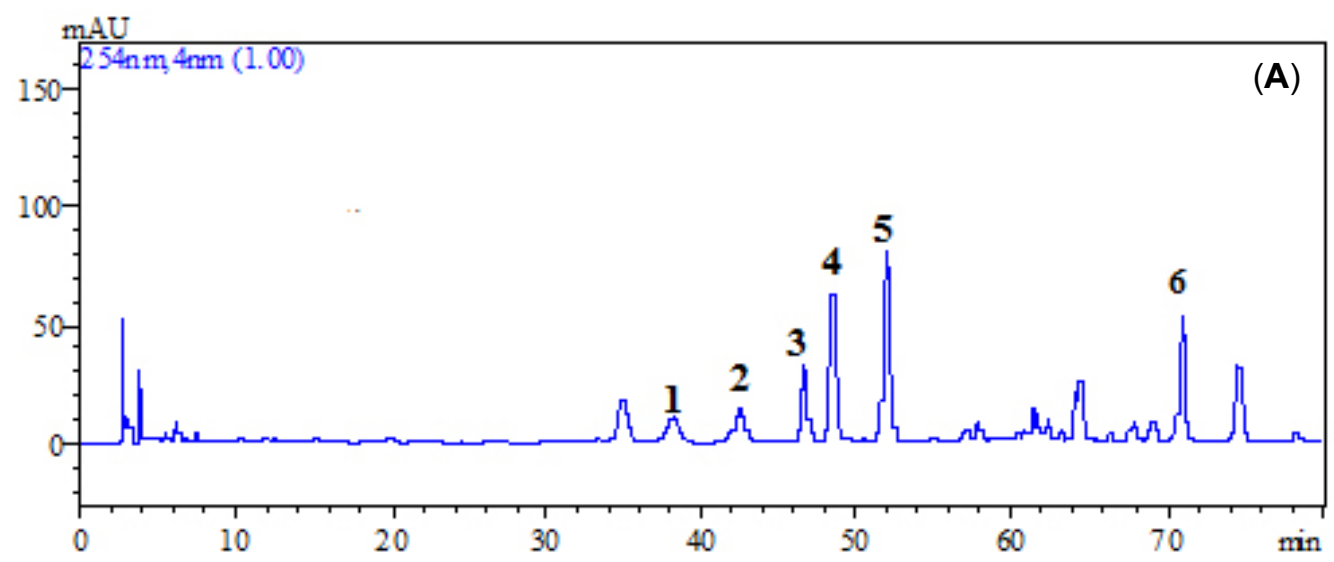


Figure 3. Cont.
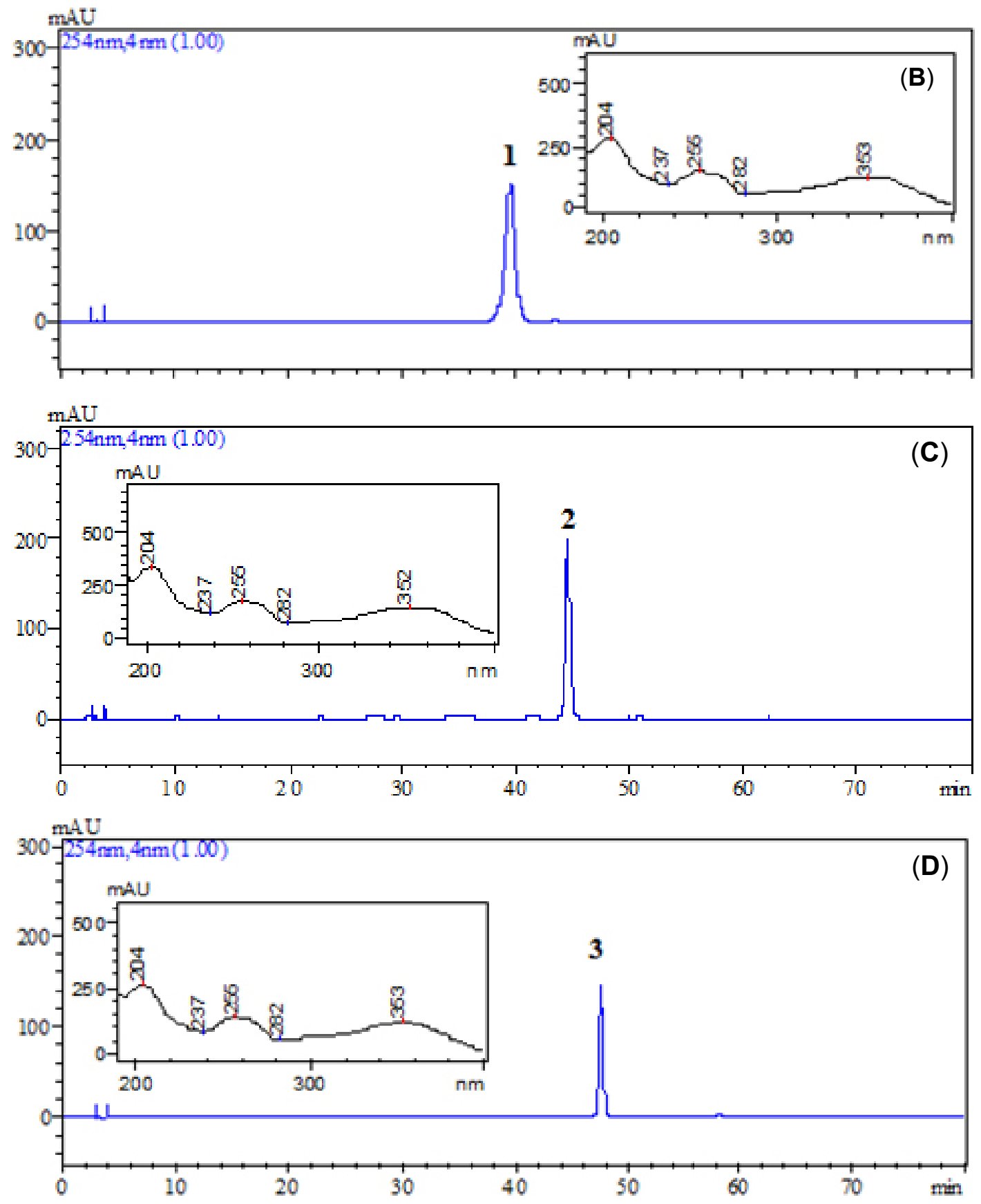

$$
\mathrm{mAU}
$$

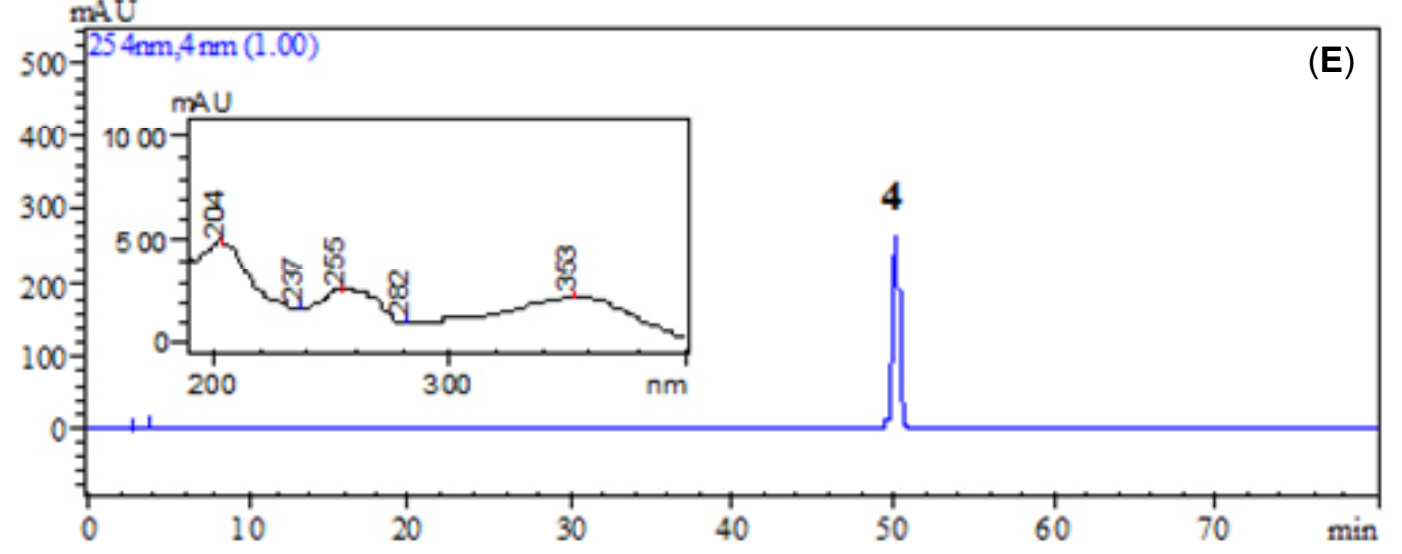


Figure 3. Cont.
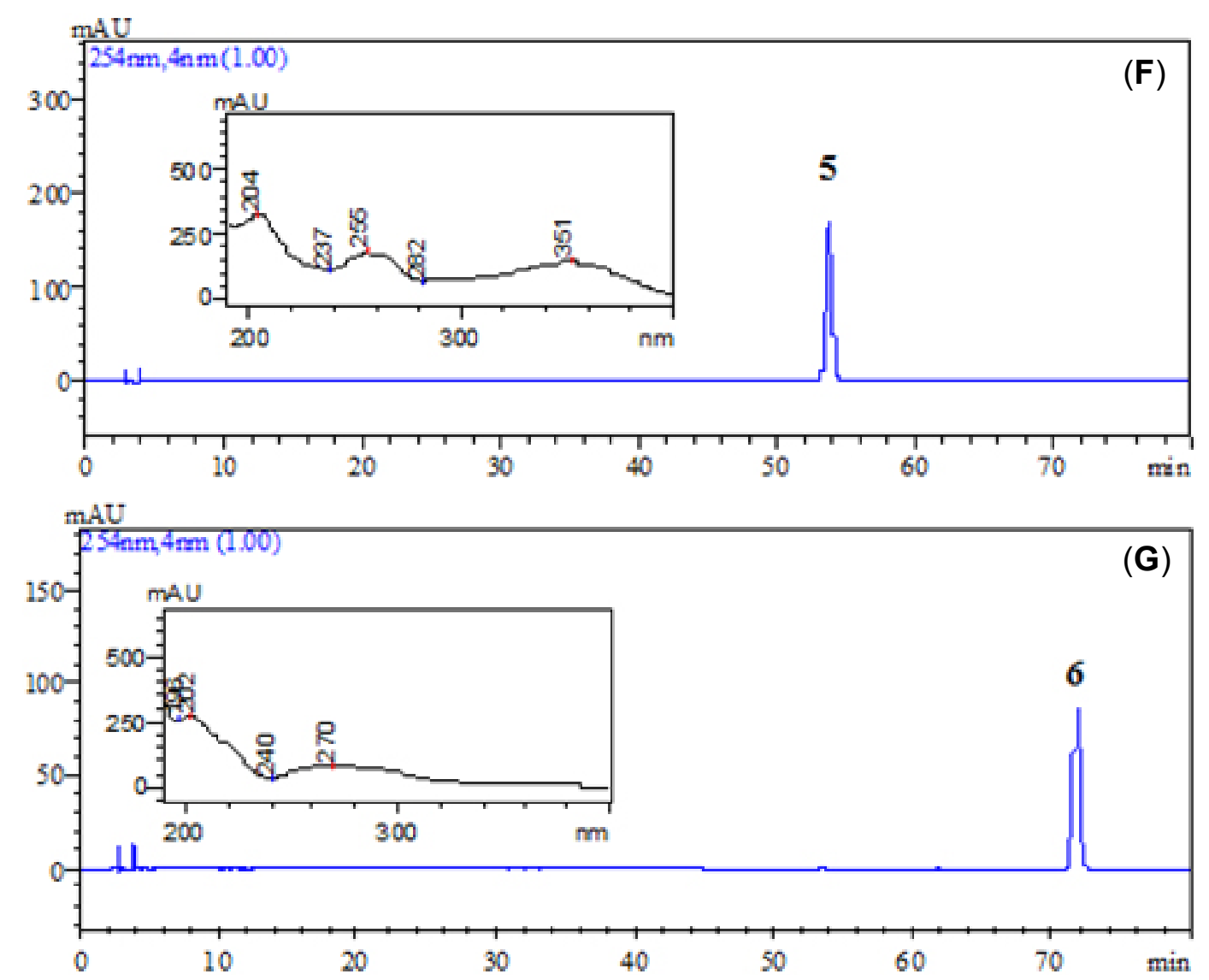

As shown in Figure 3B-G, the HPLC analysis of each of the HSCCC fractions revealed that the purities of these six compounds were $98.1 \%, 98.9 \%, 95.4 \%, 99.5 \%, 99.7 \%$ and $98.4 \%$, respectively. In order to save solvents and time, the compounds with higher $K$ values, which were still retained in the column after compound $\mathbf{6}$ was eluted, were removed by forcing out the stationary phase by air compressor. After each run, the column was cleaned with $100 \mathrm{~mL}$ of ethanol.

\section{Experimental}

\subsection{Materials and Reagents}

The dried leaves of $P$. guajava were purchased from Beijing Twinbridge Yanjing Chinese Medicine Yinpian Factory (Beijing, China) in 2011. Effective plant leaves identification was provided by Professor Chunsheng Liu of the College of Traditional Chinese Medicine, Beijing University of Chinese Medicine, and the voucher specimen (201103012) was deposited in the Health-cultivation Laboratory of the Ministry of Education, Beijing, China. All organic solvents used for sample preparation and HSCCC were of analytical grade and purchased from the Beijing Chemical Works (Beijing, China). Methanol used for HPLC analysis was of chromatographic grade, and was purchased from Thermo Fisher Scientific Inc. (Waltham, MA, USA), and water (18.2 M $\Omega$ ) was produced by a Milli-Q system (Millipore, Bedford, MA, USA). They were filtered and degassed prior to use. 


\subsection{Apparatus}

A TBE-300B high-speed counter-current chromatography instrument (Shanghai Tauto Biotech Co., Ltd, Shanghai, China) with three polytetrafluoroethylene (PTFE) preparative coils (total volume: $340 \mathrm{~mL}$ ) and a $20 \mathrm{~mL}$ sample loop were used for HSCCC. Solvents were delivered by a TBP 5002 (Shanghai Tauto Biotech Co., Ltd, Shanghai, China) pump. The UV-absorbance of the eluent was monitored by a TBD 2000 UV detector (Shanghai Tauto Biotech Co., Ltd, Shanghai, China) at the wavelength of $254 \mathrm{~nm}$. A DC-0506 constant-temperature circulating implement (Shanghai Sunny Hengping Scientific Instrument Co., Ltd, Shanghai, China) was used to control the separation temperature. The data were collected using a HW-2000 chromatography workstation (Shanghai Qianpu Software Ltd., Shanghai, China). A FB-36/7 air compressor pump was used to force out the stationary phase. The analytical HPLC equipment was a LC-15C equipped with a SPD-M20A diode array detector, and a LCsolution chromatography workstation (Shimadzu, Kyoto, Japan). Semi-preparative HPLC was performed on a CXTH LC-3000 HPLC system with a CXTH LC-3000 UV spectrophotometric detector (Beijing Chuangxintongheng Science and Technology Co., Ltd., Beijing, China). The nuclear magnetic resonance (NMR) spectrometer was a Bruker AVANCE $600 \mathrm{MHz}$ NMR (Bruker Spectrospin, Fällanden, Switzerland) with tetramethylsilane (TMS) as the internal standard.

Figure 4. The sample preparation scheme.

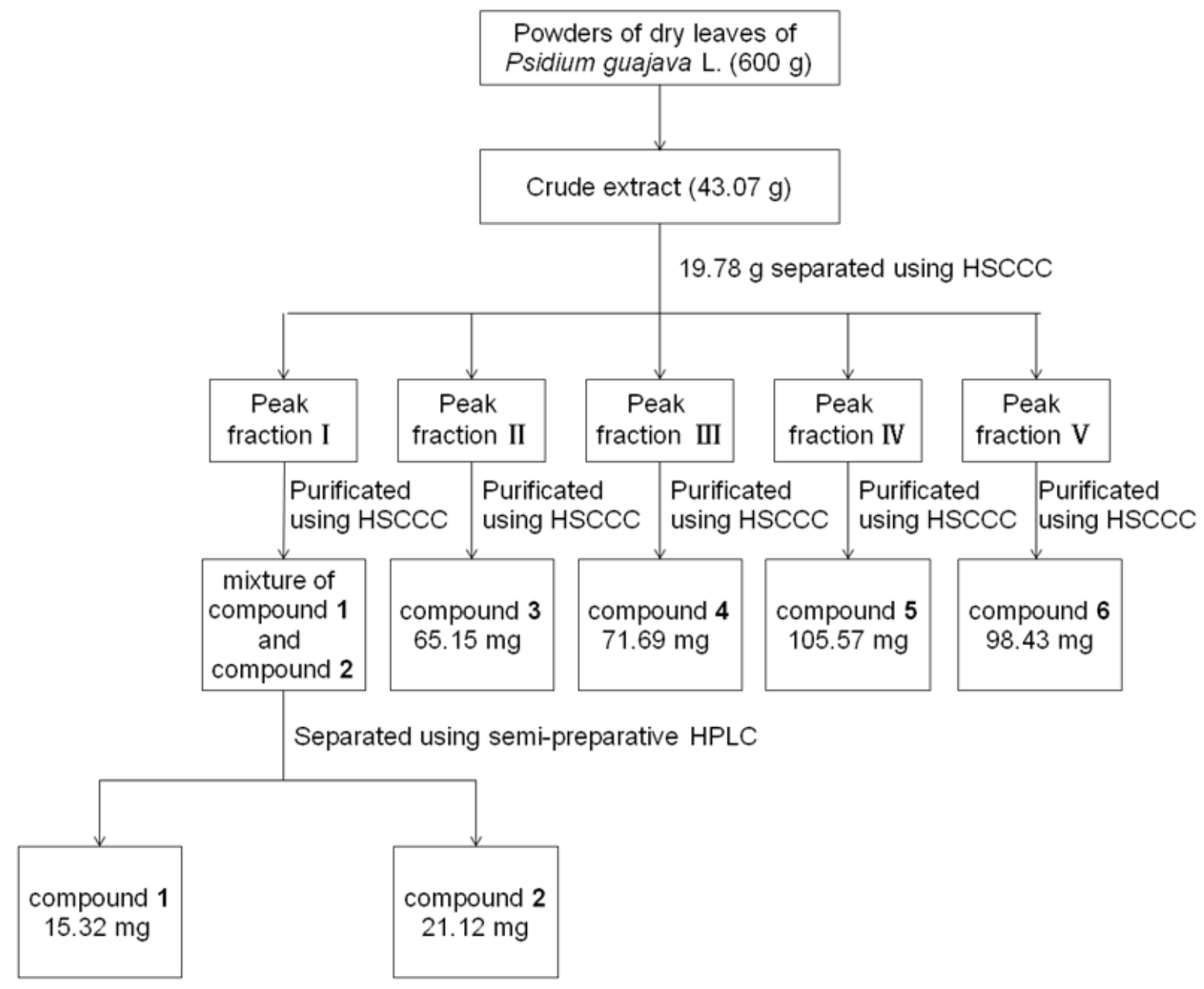




\subsection{Preparation of the Crude Sample}

The dried leaves $(600 \mathrm{~g})$ of $P$. guajava was crushed with a grinder (Tianjin Taisite Instrument Co., LTD., Tianjin, China) and ultrasonically extracted seven times using ethyl acetate, each time with $2.5 \mathrm{~L}$ for $1 \mathrm{~h}$. Then the extract was filtered and evaporated to dryness by rotary evaporation at $40{ }^{\circ} \mathrm{C}$ under reduced pressure, and dried in a vacuum oven at $60{ }^{\circ} \mathrm{C}$ for $24 \mathrm{~h}(43.05 \mathrm{~g})$ and part of the dried extract (19.78 g) were prepared for subsequent HSCCC isolation and purification. The sample preparation scheme is shown in Figure 4.

\subsection{Selection of the Solvent System}

The partition coefficient is the ratio of the solute distributed between the mutually equilibrated two solvent phases. The partition coefficients were determined by HPLC as follows. A suitable amount of crude sample was added into a series of pre-equilibrated two-phase solvent systems, and the solution was then shaken fully. Subsequently, the same volume of each of upper and lower phases was evaporated to dryness. The residues were diluted into $2 \mathrm{~mL}$ methanol and then analysed by HPLC. The $K$ value was defined as the peak area of the component in the upper phase divided by the peak area of the component in the lower phase.

\subsection{Preparation of the Two-Phase Solvent Systems and Sample Solution}

A solvent system consisting of $n$-hexane-ethyl acetate-methanol-water $(0.7: 4: 0.8: 4, \mathrm{v} / \mathrm{v} / \mathrm{v} / \mathrm{v})$ was used for the separation of the ethyl acetate extract. A solvent system consisting of $n$-hexane-ethyl acetate-methanol-water $(0.3: 3: 0.1: 3, \mathrm{v} / \mathrm{v} / \mathrm{v} / \mathrm{v})$ was used for the purification of mixture of compound 1 and compound 2. A solvent system consisting of $n$-hexane-ethyl acetate-methanol-water (0.7:4:0.8:4, $\mathrm{v} / \mathrm{v} / \mathrm{v} / \mathrm{v}$ ) was used for the purification of compounds 3, 4 and 5. A solvent system consisting of $n$-hexane-ethyl acetate-methanol-water $(1: 3: 1: 3, \mathrm{v} / \mathrm{v} / \mathrm{v} / \mathrm{v})$ was used for the purification of compound 6. All solvent systems were thoroughly mixed, vented in a separatory funnel at room temperature and allowed to separate into two distinct phases before use. The sample solution was prepared by dissolving $600 \mathrm{mg}$ of crude extract in $14 \mathrm{~mL}$ mixture of lower phase and upper phase $(1: 1, \mathrm{v} / \mathrm{v})$ of the solvent system used for HSCCC separation.

\subsection{Separation and Purification by HSCCC}

The coiled column was filled with the upper phase. After the column was entirely filled, the apparatus was rotated at $900 \mathrm{rpm}$, while the lower phase (mobile phase) was pumped into the column at a flow rate of $2.5 \mathrm{~mL} / \mathrm{min}$. After hydrodynamic equilibrium was reached, as indicated by the emergence of the mobile phase front, a $14 \mathrm{~mL}$ sample solution containing $600 \mathrm{mg}$ of the crude powder was injected into the column through the injection valve. The effluent from the tail end of the column was continuously monitored with a UV detector at $254 \mathrm{~nm}$, and the chromatogram was recorded. The temperature of the apparatus was set to $25^{\circ} \mathrm{C}$. The peak fractions were collected manually according to the elution profile and evaporated under reduced pressure, and the residues were dissolved in methanol for subsequent purity analysis by HPLC. The purity was obtained by HPLC peak area calculation. 


\subsection{Separation of Mixture of Compound $\mathbf{1}$ and Compound $\mathbf{2}$ by Semi-Preparative HPLC}

The mixture of compounds $\mathbf{1}$ and $\mathbf{2}$ was separated by semi-preparative HPLC performed with a Thermo Scientific Hypersil Gold Phenyl column $(5 \mu \mathrm{m}, 10 \times 250 \mathrm{~mm})$. The mobile phase solvents consisted of water as eluent $\mathrm{A}$ and acetonitrileas eluent B $(87: 13, \mathrm{v} / \mathrm{v})$. The flow-rate was $2.0 \mathrm{~mL} / \mathrm{min}$ and $1.0 \mathrm{~mL}$ of sample solution $(1 \mathrm{mg} / \mathrm{mL}$ of fraction I from HSCCC separation in methanol) was injected through the sample injector. The effluent from the outlet of the column was monitored at $254 \mathrm{~nm}$. The peak fractions were collected according to the chromatogram.

\subsection{HPLC Analysis}

The crude extract and each peak fraction obtained by HSCCC were analysed by HPLC. The HPLC analyses were carried out using a Thermo Scientific Syncronis C18 column $(250 \times 4.6 \mathrm{~mm} \mathrm{ID,} 5 \mu \mathrm{m})$. The HPLC solvents were $\mathrm{H}_{2} \mathrm{O}$ with $0.2 \%$ phosphoric acid (v/v) as an aqueous solvent (A) and $\mathrm{CH}_{3} \mathrm{CN}$ as an organic solvent (B). The gradient condition was as follows: 0-35 min, 14\% B; 35-40 min, $14 \%-18 \% \mathrm{~B}$; $40-50 \mathrm{~min}, 18 \% \mathrm{~B}, 50-55 \mathrm{~min}, 18 \%-25 \% \mathrm{~B} ; 55-75 \mathrm{~min}, 25 \% \mathrm{~B}$. A flow rate was set at $1.0 \mathrm{~mL} / \mathrm{min}$, a column temperature was $40{ }^{\circ} \mathrm{C}$ and sample injection volume was $20 \mu \mathrm{L}$.

\subsection{Identification of Target Compounds}

The chemical structures of peak fractions separated by HSCCC were identified according to their ESI-MS, ${ }^{1} \mathrm{H}-\mathrm{NMR}$ and ${ }^{13} \mathrm{C}-\mathrm{NMR}$ data. The data of each peak fraction are provided below.

Compound 1. Light yellow powder, ESI-MS (+ve ion mode): $m / z 465.1[\mathrm{M}+\mathrm{H}]^{+}, 487.1[\mathrm{M}+\mathrm{Na}]^{+}$; ${ }^{1} \mathrm{H}-\mathrm{NMR}\left(\mathrm{DMSO}-d_{6}\right) \delta: 6.20(1 \mathrm{H}, \mathrm{d}, J=1.8 \mathrm{~Hz}, \mathrm{H}-6), 6.40(1 \mathrm{H}, \mathrm{d}, J=1.8 \mathrm{~Hz}, \mathrm{H}-8), 7.53(1 \mathrm{H}, \mathrm{d}$, $\left.J=1.8 \mathrm{~Hz}, \mathrm{H}-2^{\prime}\right), 6.82\left(1 \mathrm{H}, \mathrm{d}, J=8.4 \mathrm{~Hz}, \mathrm{H}-5^{\prime}\right), 7.66\left(1 \mathrm{H}, \mathrm{dd}, J=8.4,1.8 \mathrm{~Hz}, \mathrm{H}-6{ }^{\prime}\right), 5.37(1 \mathrm{H}, \mathrm{d}$, $J=7.8 \mathrm{~Hz}, \mathrm{H}-1 "), 3.17 \sim 3.66$ (6H, m, H-2"-6"); ${ }^{13} \mathrm{C}-\mathrm{NMR}$ (DMSO- $d_{6}$ ) see Table 2. By comparison with the literature data [32], compound 1 was identified as quercetin-3-O- $\beta$-D-galactopyranoside (hyperin).

Compound 2. Yellow powder, ESI-MS (+ve ion mode): $m / z$ 465.1 [M+H] ${ }^{+},{ }^{1} \mathrm{H}-\mathrm{NMR}$ (DMSO- $d_{6}$ ) $\delta: 6.19(1 \mathrm{H}, \mathrm{d}, J=1.8 \mathrm{~Hz}, \mathrm{H}-6), 6.40(1 \mathrm{H}, \mathrm{d}, J=1.8 \mathrm{~Hz}, \mathrm{H}-8), 7.58$ (2H, m, H-2', 6'), 6.84 (1H, d, $J=9.0 \mathrm{~Hz}, \mathrm{H}-5$ '), 5.46 (1H, d, $J=7.2 \mathrm{~Hz}, \mathrm{H}-1 "), 3.09 \sim 3.58$ (6H, m, H-2"-6"). ${ }^{13} \mathrm{C}-\mathrm{NMR}$ (DMSO- $d_{6}$ ) see Table 2. The ${ }^{1} \mathrm{H}-\mathrm{NMR}$ and ${ }^{13} \mathrm{C}$-NMR data were in agreement with that of quercetin-3-O- $\beta$-D-glucopyranoside (isoquercitrin) [33].

Compound 3. Light yellow powder, ESI-MS (+ve ion mode): $m / z 435.1[\mathrm{M}+\mathrm{H}]^{+},{ }^{1} \mathrm{H}-\mathrm{NMR}$ (DMSO- $d_{6}$ ) $\delta: 6.20(1 \mathrm{H}, \mathrm{d}, J=1.8 \mathrm{~Hz}, \mathrm{H}-6), 6.40(1 \mathrm{H}, \mathrm{d}, J=1.8 \mathrm{~Hz}, \mathrm{H}-8), 7.54\left(1 \mathrm{H}, \mathrm{d}, J=1.8 \mathrm{~Hz}, \mathrm{H}-2^{\prime}\right), 6.85$ $\left(1 \mathrm{H}, \mathrm{d}, J=8.4 \mathrm{~Hz}, \mathrm{H}-5^{\prime}\right), 7.57$ (1H, dd, $\left.J=8.4,1.8 \mathrm{~Hz}, \mathrm{H}-6^{\prime}\right), 5.34$ (1H, d, $\left.J=7.2 \mathrm{~Hz}, \mathrm{H}-1^{\prime \prime}\right)$, 3.20-3.63 (5H, m, H-2"-5"); ${ }^{13} \mathrm{C}-\mathrm{NMR}$ (DMSO- $d_{6}$ ) see Table 2. The ${ }^{1} \mathrm{H}-\mathrm{NMR}$ and ${ }^{13} \mathrm{C}-\mathrm{NMR}$ data were in agreement with the quercetin-3-O- $\beta$-D-xylopyranoside (reynoutrin) data found in the literature [34].

Compound 4. Yellow needle-like crystals; ESI-MS (+ve ion mode): $m / z$ 435.1[M+H] ${ }^{+},{ }^{1} \mathrm{H}-\mathrm{NMR}$ $\left(\mathrm{DMSO}-d_{6}\right) \delta: 6.20(1 \mathrm{H}, \mathrm{d}, J=1.8 \mathrm{~Hz}, \mathrm{H}-6), 6.40(1 \mathrm{H}, \mathrm{d}, J=1.8 \mathrm{~Hz}, \mathrm{H}-8), 7.51(1 \mathrm{H}, \mathrm{d}, J=1.8 \mathrm{~Hz}$, H-2'), $6.85\left(1 \mathrm{H}, \mathrm{d}, J=8.4 \mathrm{~Hz}, \mathrm{H}-5^{\prime}\right), 7.66(1 \mathrm{H}, \mathrm{dd}, J=8.4,1.8 \mathrm{~Hz}, \mathrm{H}-6$ '), $5.27(1 \mathrm{H}, \mathrm{d}, J=5.4 \mathrm{~Hz}$, $\mathrm{H}-1 "), 3.20 \sim 3.75$ (5H, m, H-2"-5"); ${ }^{13} \mathrm{C}-\mathrm{NMR}$ (150 MHz, DMSO- $d_{6}$ ) see Table 2. The ${ }^{1} \mathrm{H}-\mathrm{NMR}$ and ${ }^{13} \mathrm{C}-\mathrm{NMR}$ data were in agreement with that of quercetin-3-O- $\beta$-D-arabinopyranoside [25]. 
Compound 5. Yellow powder; ESI-MS (+ve ion mode): $m / z$ 435.1 [M+H] ${ }^{+},{ }^{1} \mathrm{H}-\mathrm{NMR}$ (DMSO- $d_{6}$ ) $\delta: 6.20(1 \mathrm{H}, \mathrm{d}, J=2.4 \mathrm{~Hz}, \mathrm{H}-6), 6.41(1 \mathrm{H}, \mathrm{d}, J=2.4 \mathrm{~Hz}, \mathrm{H}-8), 7.48\left(1 \mathrm{H}, \mathrm{d}, J=2.4 \mathrm{~Hz}, \mathrm{H}-2{ }^{\prime}\right), 6.85(1 \mathrm{H}, \mathrm{d}$, $\left.J=8.4 \mathrm{~Hz}, \mathrm{H}-5^{\prime}\right), 7.55$ (1H, dd, $J=8.4,1.8 \mathrm{~Hz}, \mathrm{H}-6$ '), 5.27 (1H, d, $\left.J=5.4 \mathrm{~Hz}, \mathrm{H}-1^{\prime \prime}\right), 3.28 \sim 3.72(5 \mathrm{H}, \mathrm{m}$, H-2"-5"). ${ }^{13} \mathrm{C}-\mathrm{NMR}$ (DMSO- $d_{6}$ ) see Table 2. The ${ }^{1} \mathrm{H}-\mathrm{NMR}$ and ${ }^{13} \mathrm{C}-\mathrm{NMR}$ data were in agreement with the quercetin-3-O- $\alpha$-L-arabinofuranoside data found in the literature [25].

Compound 6. Brownish yellow powder; ESI-MS (+ive ion mode): $m / z 573.2[\mathrm{M}+\mathrm{H}]^{+}, 595.2[\mathrm{M}+\mathrm{Na}]^{+}$, ESI-MS (-ve ion mode): $m / z$ 571.1[M-H] ${ }^{-} .{ }^{1} \mathrm{H}-\mathrm{NMR}\left(\mathrm{DMSO}-d_{6}\right) \delta: 7.65(2 \mathrm{H}, \mathrm{dd}, J=7.2,1.2 \mathrm{~Hz}$, H-2', 6'), 7.46 (2 H, t, $\left.J=7.2 \mathrm{~Hz}, \mathrm{H}-3^{\prime}, 5^{\prime}\right), 7.55$ (t, $J=7.2 \mathrm{~Hz}, \mathrm{H}-4$ '), 2.00 (6 H, s, 3',5'-CH3), 4.63 $(1 \mathrm{H}, \mathrm{d}, J=7.8 \mathrm{~Hz}, \mathrm{H}-1 "), 6.96$ ( $\left.2 \mathrm{H}, \mathrm{s}, \mathrm{H}-2{ }^{\prime \prime}, 66^{\prime \prime \prime)}\right){ }^{13} \mathrm{C}-\mathrm{NMR}$ (DMSO-d $) \delta: 113.1$ (C-1), 152.2 (C-2), 110.8 (C-3), 156.0 (C-4), 110.8 (C-5), 152.2 (C-6), 138.9 (C-1'), 128.7(C-2'), 128.2 (C-3'), 132.3 (C-4'), 128.2 (C-5'), 128.7 (C-6'), 196.9 (aglycone, C=O), 9.8 (3'-CH $), 9.8\left(5^{\prime}-\mathrm{CH}_{3}\right), 104.1\left(\mathrm{C}-1^{\prime \prime}\right), 74.2\left(\mathrm{C}-2^{\prime \prime}\right)$, 76.1 (C-3"), 69.3 (C-4"), 73.4(C-5"), 62.7 (C-6"), 119.5 (C-1"'), 108.5(C-2"'), 145.3 (C-3"'), 138.4 (C-4"'), 145.3 (C-5"'), 108.5 (C-6"'). The ${ }^{1} \mathrm{H}-\mathrm{NMR}$ and ${ }^{13} \mathrm{C}-\mathrm{NMR}$ data were in agreement with that of 2,4,6-trihydroxy-3,5-dimethylbenzophenone 4-O-(6"-O-galloyl)- $\beta$-D-glucopyranoside data found in the literature [26].

Table 2. ${ }^{13} \mathrm{C}-\mathrm{NMR}$ Data of compounds $\mathbf{1}-\mathbf{5}$.

\begin{tabular}{cccccc}
\hline Atom & $\mathbf{1}$ & $\mathbf{2}$ & $\mathbf{3}$ & $\mathbf{4}$ & $\mathbf{5}$ \\
\hline 2 & 156.2 & 156.1 & 156.1 & 156.2 & 156.3 \\
3 & 133.5 & 133.3 & 133.1 & 133.7 & 133.4 \\
4 & 177.5 & 177.4 & 177.3 & 177.5 & 177.7 \\
5 & 161.2 & 161.2 & 161.1 & 161.2 & 161.2 \\
6 & 98.6 & 98.6 & 98.7 & 98.6 & 98.6 \\
7 & 164.1 & 164.2 & 164.1 & 164.1 & 164.2 \\
8 & 93.5 & 93.5 & 93.5 & 93.5 & 93.5 \\
9 & 156.3 & 156.3 & 156.2 & 156.2 & 156.9 \\
10 & 103.9 & 103.9 & 103.8 & 103.9 & 103.9 \\
$1^{\prime}$ & 121.1 & 121.1 & 120.9 & 120.9 & 120.9 \\
$2^{\prime}$ & 115.9 & 116.2 & 116.1 & 115.3 & 115.5 \\
$3^{\prime}$ & 144.8 & 144.8 & 144.8 & 144.9 & 145.0 \\
$4^{\prime}$ & 148.4 & 148.4 & 148.4 & 148.6 & 148.4 \\
$5^{\prime}$ & 115.1 & 115.2 & 115.3 & 115.7 & 115.5 \\
$6^{\prime}$ & 121.9 & 121.6 & 121.4 & 122.0 & 121.7 \\
$1^{\prime \prime}$ & 101.8 & 100.9 & 101.7 & 101.4 & 107.8 \\
$2^{\prime \prime}$ & 71.2 & 74.1 & 73.5 & 71.6 & 82.1 \\
$3^{\prime \prime}$ & 73.2 & 76.5 & 75.9 & 70.7 & 76.9 \\
$4^{\prime \prime}$ & 67.9 & 69.9 & 69.3 & 66.0 & 85.8 \\
$5^{\prime \prime}$ & 75.8 & 77.5 & 66.0 & 64.2 & 60.6 \\
$6^{\prime \prime}$ & 60.1 & 61.0 & & & \\
\hline & & & & &
\end{tabular}

\section{Conclusions}

This study demonstrates that HSCCC was a useful method for separating and isolating flavonoid glycosides and a benzophenone galloyl glycoside from the ethyl acetate extract from $P$. guajava leaves 
with a two-phase solvent system composed of $n$-hexane-ethyl acetate-methanol-water (0.7:4:0.8:4, $\mathrm{v} / \mathrm{v} / \mathrm{v} / \mathrm{v}$ ), confirming that HSCCC is an efficient technique to isolate and purificate pure bioactive compounds from natural products. Compared with the more extensive use of chromatography and preparative HPLC in natural product research, crude samples can be used in HSCCC and the sample size is larger. HSCCC has some shortcomings, such as poor efficiency and time consumption. As an emerging separation technology, the methods and techniques of HSCCC need further research.

\section{Acknowledgments}

The authors are grateful to the International Science \& Technology Cooperation Program of China (2010DFB33260) and the Cooperation Program of Beijing Municipal Education Commission and the Innovative team of Beijing TCM University (2011-CXTD-19).

\section{Conflicts of Interest}

The authors declare no conflict of interest.

\section{References}

1. Gutierrez, R.M.; Mitchell, S.; Solis, R.V. Psidium guajava: A review of its traditional uses, phytochemistry and pharmacology. J. Ethnopharmacol. 2008, 117, 1-27.

2. Juarez-Vazquez Mdel, C.; Carranza-Alvarez, C.; Alonso-Castro, A.J.; Gonzalez-Alcaraz, V.F.; Bravo-Acevedo, E.; Chamarro-Tinajero, F.J.; Solano, E. Ethnobotany of medicinal plants used in Xalpatlahuac, Guerrero, Mexico. J. Ethnopharmacol. 2013, 148, 521-527.

3. McCook-Russell, K.P.; Nair, M.G.; Facey, P.C.; Bowen-Forbes, C.S. Nutritional and nutraceutical comparison of Jamaican Psidium cattleianum (strawberry guava) and Psidium guajava (common guava) fruits. Food Chem. 2012, 134, 1069-1073.

4. Lin, C.Y.; Yin, M.C. Renal protective effects of extracts from guava fruit (Psidium guajava L.) in diabetic mice. Plant Foods Hum. Nutr. 2012, 67, 303-308.

5. Owen, P.L.; Martineau, L.C.; Caves, D.; Haddad, P.S.; Matainaho, T.; Johns, T. Consumption of guava (Psidium guajava L.) and noni (Morinda citrifolia L.) may protect betel quid-chewing Papua New Guineans against diabetes. Asia Pac. J. Clin. Nutr. 2008, 17, 635-643.

6. Ojewole, J.A.; Awe, E.O.; Chiwororo, W.D. Antidiarrhoeal activity of Psidium guajava Linn. (Myrtaceae) leaf aqueous extract in rodents. J. Smooth Muscle Res. 2008, 44, 195-207.

7. Cheng, F.C.; Shen, S.C.; Wu, J.S. Effect of guava (Psidium guajava L.) leaf extract on glucose uptake in rat hepatocytes. J. Food Sci. 2009, 74, H132-H138.

8. Shen, S.C.; Cheng, F.C.; Wu, N.J. Effect of guava (Psidium guajava L.) leaf soluble solids on glucose metabolism in type 2 diabetic rats. Phytother. Res. 2008, 22, 1458-1464.

9. Soman, S.; Rauf, A.A.; Indira, M.; Rajamanickam, C. Antioxidant and antiglycative potential of ethyl acetate fraction of Psidium guajava leaf extract in streptozotocin-induced diabetic rats. Plant Foods Hum. Nutr. 2010, 65, 386-391. 
10. Shabana, S.; Kawai, A.; Kai, K.; Akiyama, K.; Hayashi, H. Inhibitory activity against urease of quercetin glycosides isolated from Allium cepa and Psidium guajava. Biosci. Biotechnol. Biochem. 2010, 74, 878-880.

11. Choi, J.H.; Park, B.H.; Kim, H.G.; Hwang, Y.P.; Han, E.H.; Jin, S.W.; Seo, J.K.; Chung, Y.C.; Jeong, H.G. Inhibitory effect of Psidium guajava water extract in the development of 2,4-dinitrochlorobenzene-induced atopic dermatitis in NC/Nga mice. Food Chem. Toxicol. 2012, 50, 2923-2929.

12. Chen, K.C.; Hsieh, C.L.; Huang, K.D.; Ker, Y.B.; Chyau, C.C.; Peng, R.Y. Anticancer activity of rhamnoallosan against DU-145 cells is kinetically complementary to coexisting Polyphenolics in Psidium guajava budding leaves. J. Agric. Food Chem. 2009, 57, 6114-6122.

13. Livingston Raja, N.R.; Sundar, K. Psidium guajava Linn confers gastro protective effects on rats. Eur. Rev. Med. Pharmacol. Sci. 2012, 16, 151-156.

14. Rattanachaikunsopon, P.; Phumkhachorn, P. Bacteriostatic effect of flavonoids isolated from leaves of Psidium guajava on fish pathogens. Fitoterapia 2007, 78, 434-436.

15. Shu, J.C.; Chou, G.X.; Wang, Z.T. One new galloyl glycoside from fresh leaves of Psidium guajava L. Acta Pharm. Sin. 2010, 45, 334-337.

16. Shu, J.C.; Chou, G.X.; Wang, Z.T. One new diphenylmethane glycoside from the leaves of Psidium guajava L. Nat. Prod. Res. 2012, 26, 1971-1975.

17. Shao, M.; Wang, Y.; Jian, Y.Q.; Huang, X.J.; Zhang, D.M.; Tang, Q.F.; Jiang, R.W.; Sun, X.G.; Lv, Z.P.; Zhang, X.Q.; et al. Guadial A and psiguadials C and D, three unusual meroterpenoids from Psidium guajava. Org. Lett. 2012, 14, 5262-5265.

18. Gao, Y.; Wang, G.Q.; Wei, K.; Hai, P.; Wang, F.; Liu, J.K. Isolation and biomimetic synthesis of (+/-)-guajadial B, a novel meroterpenoid from Psidium guajava. Org. Lett. 2012, 14, 5936-5939.

19. Begum, S.; Hassan, S.I.; Ali, S.N.; Siddiqui, B.S. Chemical constituents from the leaves of Psidium guajava. Nat. Prod. Res. 2004, 18, 135-140.

20. Eidenberger, T.; Selg, M.; Krennhuber, K. Inhibition of dipeptidyl peptidase activity by flavonol glycosides of guava (Psidium guajava L.): A key to the beneficial effects of guava in type II diabetes mellitus. Fitoterapia 2013, 89, 74-79.

21. Yang, L.; Li, X.F.; Gao, L.; Zhang, Y.O.; Cai, G.P. Suppressive effects of quercetin-3-O-(6"-Feruloyl)-beta-D-galactopyranoside on adipogenesis in 3T3-L1 preadipocytes through down-regulation of PPARgamma and C/EBPalpha expression. Phytother. Res. 2012, 26, $438-444$.

22. Liu, R.L.; Xiong, Q.J.; Shu, Q.; Wu, W.N.; Cheng, J.; Fu, H.; Wang, F.; Chen, J.G.; Hu, Z.L. Hyperoside protects cortical neurons from oxygen-glucose deprivation-reperfusion induced injury via nitric oxide signal pathway. Brain Res. 2012, 1469, 164-173.

23. Fujii, Y.; Kimura, M.; Ishii, Y.; Yamamoto, R.; Morita, R.; Hayashi, S.M.; Suzuki, K.; Shibutani, M. Effect of enzymatically modified isoquercitrin on preneoplastic liver cell lesions induced by thioacetamide promotion in a two-stage hepatocarcinogenesis model using rats. Toxicology 2013, 305, 30-40.

24. Schmidt, J.S.; Lauridsen, M.B.; Dragsted, L.O.; Nielsen, J.; Staerk, D. Development of a bioassay-coupled HPLC-SPE-ttNMR platform for identification of alpha-glucosidase inhibitors in apple peel (Malus xdomestica Borkh.). Food Chem. 2012, 135, 1692-1699. 
25. Metwally, A.M.; Omar, A.A.; Harraz, F.M.; El Sohafy, S.M. Phytochemical investigation and antimicrobial activity of Psidium guajava L. leaves. Pharmacogn. Mag. 2010, 6, 212-218.

26. Matsuzaki, K.; Ishii, R.; Kobiyama, K.; Kitanaka, S. New benzophenone and quercetin galloyl glycosides from Psidium guajava L. J. Nat. Med. 2010, 64, 252-256.

27. Ito, Y. Golden rules and pitfalls in selecting optimum conditions for high-speed counter-current chromatography. J. Chromatogr. A 2005, 1065, 145-168.

28. Han, L.; Ji, L.; Boakye-Yiadom, M.; Li, W.; Song, X.; Gao, X. Preparative isolation and purification of four compounds from Cistanches deserticola Y.C. Ma by high-speed counter-current chromatography. Molecules 2012, 17, 8276-8284.

29. Faure, K.; Bouju, E.; Suchet, P.; Berthod, A. Use of limonene in countercurrent chromatography: A green alkane substitute. Anal. Chem. 2013, 85, 4644-4650.

30. Du, Q.; Jiang, Z.; Wang, D. Excellent combination of counter-current chromatography and preparative high-performance liquid chromatography to separate galactolipids from pumpkin. J. Chromatogr. A 2009, 1216, 4176-4180.

31. Cao, X.L. HSCCC Technology and Application; Chemical Industry Press: Beijing, China, 2005; pp. 71-78.

32. Lee, S.Y.; Kim, K.H.; Lee, I.K.; Lee, K.H.; Choi, S.U.; Lee, K.R. A new flavonol glycoside from Hylomecon vernalis. Arch. Pharm. Res. 2012, 35, 415-421.

33. Nguelefack, T.B.; Mbakam, F.H.; Tapondjou, L.A.; Watcho, P.; Nguelefack-Mbuyo, E.P.; Ponou, B.K.; Kamanyi, A.; Park, H.J. A dimeric triterpenoid glycoside and flavonoid glycosides with free radical-scavenging activity isolated from Rubus rigidus var. camerunensis. Arch. Pharm. Res. 2011, 34, 543-550.

34. Camargo, L.M.D.M.; Férézoub, J.-P.; Tinoco, L.W.; Kaiser, C.R.; Costa, S.S. Flavonoids from Mimosa xanthocentra (Leguminosae: Mimosoideae) and molecular modeling studies for isovitexin-2"-O- $\alpha$-L-rhamnopyranoside rotamers. Phytochem. Lett. 2012, 5, 427-431.

Sample Availability: Samples of the compounds are available from the authors.

(C) 2013 by the authors; licensee MDPI, Basel, Switzerland. This article is an open access article distributed under the terms and conditions of the Creative Commons Attribution license (http://creativecommons.org/licenses/by/3.0/). 